\title{
АНТИОКСИДАЗНЫЕ СВОЙСТВА ДЕКОРАТИВНЫХ РАСТЕНИЙ
}

\author{
Панфилова О. Ф., Пильщикова Н. В. \\ Федеральное государственное бюджетное \\ образовательное учреждение высшего образования \\ «Российский государственный аграрный университет-МСХА \\ им. К. А. Тимирязева», \\ 2. Москва, Россия, e-mail: sad200805@mail.ru
}

В обзорной статье обсуждаются проблемы послеуборочной физиологии декоративных растений в связи с состоянием антиоксидантных систем во время развития и старения цветков. Представлены достижения молекулярной биологии в изучении механизмов регуляции клеточного старения, роли в этом процессе активных форм кислорода и антиоксидантных систем. Особое внимание обращено на изменения содержания полифенолов в стареющих лепестках. Установлено, что изменение активности ферментов антиоксидантного комплекса происходит раньше видимых признаков утраты декоративной ценности. В период старения возросший уровень АФК связан не только с повышенным образованием радикалов, но и с потерей компенсаторной функции антиоксидантных систем. Показана перспективность использования 5-сульфосалициловой кислоты для замедления старения срезанных цветов.

Ключевые слова: антиоксиданты, аутофагия, декоративные растения, жизнь в вазе, окислительно-восстановительная сигнализация, 5-сульфосалициловая кислота, старение лепестков.

В настоящее время все большее внимание уделяется декоративным растениям как источнику физиологически активных веществ. Современные методы анализа состава цветков, достижения метаболомики в области изучения биохимических процессов при развитии и старении 
Глава 6. Физиология и биохимия растений

цветков позволяют не только с большой долей вероятности судить об их пищевой ценности, но и контролировать нежелательное накопление ядовитых веществ. Цветки издавна используются как источник лекарственных веществ и в кулинарии. Большое значение имеют их антиоксидантные свойства, способные устранить негативное действие свободных радикалов. У людей антиоксиданты играют важную роль в предотвращении некоторых дегенеративных заболеваний и патологий, связанных со стрессом.

В составе растения наиболее богаты физиологически активными веществами цветки, среди них особое значение имеют фенольные соединения и каротиноиды. Их высоким содержанием отличаются Antigonon leptopus Hook \& Arn, Bougainvillea glabra Choisy, Tagetes erecta L., Cosmos sulphureus Cav., Prunus mume S \& Z и Sophora viciifolia L. [8]. Одной из наиболее распространённых групп фенольных соединений являются флавоноиды. Среди них пигменты цветков - флавоны (жёлтые) и антоцианы, обеспечивающие многообразие окраски широкого спектра оттенков - от розового до чёрно-фиолетового. Их окраска зависит от замещающих группировок и $\mathrm{pH}$. Большинство флавоноидов обнаруживается в клеточном соке, но небольшие количества могут присутствовать в хлоропластах. Содержание флавоноидов в среднем составляет 0,5-5 \%. В бутонах Sophorae japonicae L. может достигать 20 \% [1].

Научно обоснованная терапевтическая эффективность природных антиоксидантов стимулирует изучение состава и антиоксидазной активности экстрактов из растительных объектов. Особое внимание уделяется растениям, широко используемым в восточной медицине. Проведено детальное изучение 15 Chrysanthemum morifolium Ramat cv. Hangbaiju, включающих 6 'Duoju' and 9 'Taiju' из разных провинций Китая с широким спектром фармакологического действия [10]. В соцветиях обнаружено 14 фенольных соединений, включая 3 монокафеоилхиновые кислоты, 3 дикафеоилхиновые кислоты, 1 фенольную кислоту и 7 флавоноидов 'Duoju' и 'Таiju' содержат различные концентрации фенольных соединений. При этом 'Таiјu' демонстрирует более высокое содержание кофеоилхиновой кислоты и более высокую антиоксидантную активность, чем 'Duoju'. B процессе развития соцветий Ch. morifolium изменялось содержание флавоноидов. В начале цветения возрастала активность ключевого фермента биосинтеза флавоноидов - халькон изомеразы (CHI) и флавоноиды постепенно накапливались. Наиболее высоким их содержание было у соцветий с открытыми язычковыми и закрытыми трубчатыми цветками. Раскрытие трубчатых цветков сопровождалось снижением активности СНI и постепенным снижением содержания флавоноидов. Изменение содержания фенольных соединений 
и окраски цветков были изучены также на разных стадиях развития миниатюрной розы cv. KORcrisett [16]. При обсуждении полученных результатов авторы ссылаются на исследования, в которых было высказано представление о функционировании системы пероксидаза-фенольная кислота-аскорбат и снижении содержания фенольных соединений на более поздних стадиях развития цветка, что делает его более уязвимым для окислительного стресса [18].

Изучение антиоксидазных систем цветков Paeonia suffruticosa Andrews также подтвердило более высокую антиоксидазную активность экстрактов на ранней стадии развития цветков [14]. Современные методы анализа с использованием высокоскоростной жидкостной хроматографии и масс спектрометрии (UFLC-Q-TOF-MS) позволили идентифицировать в экстрактах из цветков Paeonia suffruticosa Andrews в общей сложности 68 соединений, в том числе 20 флавоноидов, 15 фенольных производных, 12 терпеноидов. Обсуждается их вклад в поддержание окислительно-восстановительного потенциала клеток, регулирование активности супероксиддисмутазы и глутатионпероксидазы в связи с противовоспалительной активностью и фотоактивным старением кожи.

Изменение антиоксидазной активности на протяжении развития цветка представляет интерес не только в фармакологии, но и в связи с практическим значением задержки старения для сохранения декоративных качеств цветочной продукции. Многие аспекты этой проблемы выходят на качественно новый уровень в связи со значительным прогрессом в изучении старения и запрограммированной гибели животных клеток (ЗКГ). Механизмы ЗКГ многообразны и представляют собой сложные многоэтапные процессы. Активированные рецепторы включают каскад цистеиновых протеаз. Протеолитические ферменты, участвующие в регуляции ЗГК растений, локализуются в различных компартментах клеток растений: метакаспазы в цитоплазме, вакуолярная протеаза (VPE) в вакуолях, фитаспаза в апопласте $[1,9]$. Внутренние сигналы могут восприниматься белками BAX и DRP-1, взаимодействующими друг с другом с помощью мембранных липидов. В качестве внеклеточных индукторов апоптоза у растений выступают фитогормоны (этилен, цитокинины, ауксин, абсцизовая кислота), жасмоновая и салициловая кислоты, элиситоры [3].

Морфология гибели клеток у растений и животных состоит в конденсации хроматина, фрагментации ядра, олигонуклеотидной деградации ДНК, сжатии протопласта, его дроблении на везикулы, разрыве плазмодесм. У животных апоптозные везикулы фагоцитируются соседними клетками и фагоцитами. У растений везикулы протопласта разрушаются гидролазами самих везикул [9]. 
Глава 6. Физиология и биохимия растений

У растений наиболее изучено развитие ЗГК листа как основного органа, обеспечивающего продукционный процесс. В стареющем листе происходит не только снижение фотосинтетической деятельности, но и активирование гидролитических процессов, обеспечивающих реутилизацию веществ. Причиной является усиление образования активных форм кислорода (АФК) и изменения в гормональном балансе [15].

Жизнь цветка в вазе определяется темпами старения лепестков, которое следует за физиологической зрелостью и ведёт к эндогенно регулируемой клеточной гибели. Лепестки цветков имеют листовое происхождение, и ключевой особенностью старения этих органов является реутилизация питательных веществ. Гибель клеток при естественном старении листьев и лепестков цветка имеет отличие от других видов ЗГК. Обычно ЗКГ происходит в ограниченном числе клеток органа. Листья и лепестки отмирают полностью. При этом скорость гибели клеток значительно меньше, что обеспечивает реутилизацию питательных веществ. Важно отметить, что превращение хлоропластов в геронтопласты в листьях обратимо. Удаление верхушки стебля у альстремерии приводит к восстановлению зелёной окраски нижележащих листьев. В лепестках происходят более быстрые и необратимые процессы старения. Старение клетки является активным и строго регулируемым на генетическом уровне процессом. При старении листа происходит уменьшение экспрессии генов $C A B 2, P R S, R B S$, обеспечивающих осуществление фотосинтеза и биосинтеза белка. Одновременно увеличивается экспрессия генов нуклеаз, протеаз, ферментов липидного и углеводного обмена, реутилизации веществ [4]. Листья и лепестки отличаются по характеру и продолжительности жизни. Тем не менее, показано сходство экспрессии 25-30 \% генов при старении листьев и лепестков у Arabidopsis haliana L. [1]. Общим ЗКГ листа и лепестков является реутилизация азота и углерода для формирования репродуктивных органов. В лепестках эти процессы идут более интенсивно.

В последние годы все большее внимание цветоводов привлекает альстромерия (Alstroemeria pelegrina L.). В течение последних лет нами проведена работа на перспективных гибридах 'Virginia', 'Cosmo', 'Climate', 'Granada', 'Nadya', ‘Tornado' с белой, жёлтой и красной окраской лепестков $[2,4,5]$. Развитие цветка альстромерии от бутона до опадения лепестков при лёгком прикосновении делится на 7 стадий и происходит в течение 10-12 дней. На 3-ей стадии происходит раскрытие цветка. Установлено, что индекс стабильности мембран мало изменялся до 4-ой стадии развития цветка и составлял примерно 80 \%, к 5 стадии развития цветка происходит резкое нарушение избирательной 
проницаемости мембран, и к 6-ой стадии индекс стабильности медленно снижается до 35 \%. Далее уже практически не изменяется. Белые лепестки у 'Virginia' не отличались по стабильности мембран на соответствующих стадиях развития цветка, но 4-ая, фактически переломная в развитии, происходит на 2-3 дня раньше. 'Virginia' характеризуется и меньшим временем сохранения декоративных качеств.

Учитывая большое значение накопление АФК и роль антиоксидантных ферментов в процессах старения, проведено изучение активности каталазы и пероксидазы. Активность каталазы в лепестках постепенно снижалась по мере развития цветка. Активность пероксидазы в 1,5-2,8 раза возрастала на 3 стадии развития цветка, при этом более существенное увеличение активности фермента наблюдалось у 'Virginia'. По мере развития цветка происходило изменение окраски лепестков. На белых лепестках 'Virginia' после 4 стадии появлялись прозрачные пятна. Опадали целиком прозрачные лепестки. Цвет окрашенных лепестков усиливался до 3-4 стадии. Особенно это было заметно на красных лепестках 'Tornado'. Причиной этого могло быть накопление обладающих антиоксидазной активностью флавоноидов. Старение лепестков после 4 стадии сопровождалось разрушением пигментов. Лепестки 'Cosmo' равномерно по всей площади и постепенно снижали интенсивность окраски, что связано с разрушением жёлтых пигментов, в том числе каротиноидов и хромопластов. У основания ярко-красных лепестков 'Tornado' на 4 стадии появились белые пятна, размеры которых в дальнейшем быстро увеличивались. Это может свидетельствовать о нарушении тонопласта и выходе антоцианов из вакуолей.

Сульфосалициловая кислота (5-SSA), у всех изученных сортов задерживала старение лепестков на 3-5 дней. Это может быть обусловлено сохранением избирательной проницаемости мембран за счёт блокирования активных форм кислорода и перекисного окисления липидов. Эффективность применения 5-SSA для задержки старения показана также для срезки розы [7] и гладиолуса [11].

Значение поддержания окислительно-восстановительного гомеостаза для продления жизни срезанных цветов Eustoma grandiflorum Salisb. показано также в опытах с обогащением воды газообразным водородом [17]. Положительный эффект связан со снижением перекисного окисления липидов, повышенной активностью супероксиддисмутазы, аскорбатпероксидазы, гваяколпероксидазы и каталазы.

В опытах с Anthurium andraeanum Andre показано значение высокой экспрессии генов альтернативных оксидаз, сопровождаемое более высокой активностью каталазы, супероксиддисмутазы, аскорбатпероксидазы 
Глава 6. Физиология и биохимия растений

и глутатионредуктазы, а также более высоким содержанием аскорбата и глутатиона для предупреждения повреждения срезанных цветов антуриума при холодовом хранении [6]. В литературе есть указания на использование экстрактов из листьев и семян Moinga oliefera Lam. для продления жизни в вазе срезанных цветов Rosa hybrid cv. Upper Class за счёт усиления актиоксидантной активности фенольных соединений [13]. Задержка программированной смерти клеток митохондриально зависимым путём у цветков брокколи под действием сахарозы также оказалась опосредованной усилением синтеза альтернативных оксидаз и ингибированием АФК [12].

Анализ литературы и наших экспериментальных данных позволяет заключить, что реализация программы старения в клетках начинается на ранних стадиях развития цветка. В период старения возросший уровень АФК связан не только с повышенным образованием радикалов, но и с потерей компенсаторной функции антиоксидантных систем. При этом АФК могут иметь значение как для этилен чувствительных, так и нечувствительных цветков. Резкое снижение стабильности мембран к окончанию формирования зародышевого мешка свидетельствует об аутофагном типе смерти клеток лепестков.

Исследования с использованием физиологических, биохимических и генетических подходов должны дать более чёткую картину старения и его регуляции. Для оценки общих и различающихся сигнальных путей в разных органах растения перспективным является изучение роли АФК и антиоксидантных систем. Показана перспективность использования 5-сульфосалициловой кислоты для замедления старения срезанных цветов особенно у нечувствительных к этилену видов.

\section{Библиографический список}

1. Кошкин Е.И., Адрианов В.Н., Панфилова О.Ф., Пильщикова Н.В. Физиологические основы качества продукции цветоводства. - М.: РГАУ-МСХА, 2012. - 295 с. ISBN 978-5-9675-0654-3.

2. Панфилова О.Ф., Пильщикова Н.В. Жизнь в вазе срезанных цветов гвоздики садовой и альстромерии // Субтропическое и декоративное садоводство. - 2014. - Вып. 51. - С. 248-255. - ISSN 2225-3068.

3. Панфилова О.Ф., Пильщикова Н.В. Апоптоз в жизни срезанных цветов // Сборник статей IX Международной научно-практической конференции / под редакцией Б.Н. Герасимова. - 2016. - С. 82-85. - ISBN 978-5-8356-1627-5.

4. Панфилова О.Ф., Пильщикова Н.В. Участие редокс-процессов в старении лепестков и время жизни цветов в вазе // Молекулярные аспекты редокс-метаболизма растений. Роль активных форм кислорода в жизни растений: мат-лы II Международного симпозиума и международной научной школы / редактор И.В. Максимов и др. - 2017. - C. 196-199. - ISBN 978-5-9909523-9-3.

5. Пильщикова Н.В., Панфилова О.Ф. Чувствительность к этилену и регуляция старения лепестков гвоздики и альстромерии // Доклады ТСХА. - 2016. - Вып. 288. - Ч. І. - С. 68-72. 
6. Aghdam M.S., Jannatizadeh A., Nojadeh M.S., Ebrahimzadeh A. Exogenous melatonin ameliorates chilling injury in cut anthurium flowers during low temperature storage // Postharvest Biology and Technology. - 2019. - Vol. 148. - P. 184-191. - doi: 10.1016/j.postharvbio.2018.11.008 7. Alaey M., Babalar M., Naderi R., Kafi M.Effect of pre- and postharvest salicylic acid treatment on physio-chemical attributes in relation to vase-life of rose cut flowers // Postharvest Biology and Technology. - 2011. - www.sciencedirect.com/science/journal/09255214/61/1. - P. 91-94.

8. Cavaiuolo M., Cocetta G., Ferrante A. The Antioxidants Changes in Ornamental Flowers during Development and Senescence // Antioxidants (Basel). - 2013. - Vol. 2(3). - P. 132-155. - doi: 10.3390/antiox2030132.

9. Doorn W.G., Woltering E.J. Physiology and molecular biology of petal senescence // Journal of Experimental Botany. - 2008. - Vol. 59. - № 3. - P. 435-480. - doi: 10.1093/jxb/erm356.

10. Gong J., Chu B., Gong L., Fang Z. Comparison of Phenolic Compounds and the Antioxidant Activities of Fifteen Chrysanthemum morifolium Ramat cv. Hangbaiju in China // Antioxidants. - 2019. - Vol. 8(8). - P. 325. - doi: 10.3390/antiox8080325.

11. Ezhilmathi K., Singh V.P., Arora A., Sairam R.K. Effect of 5-sulfosalicylic acid on antioxidant activity in relation to vase life of Gladiolus cut flowers // Plant Growth Regul. - 2007. - Vol. 51. - P. 99-108. - ISSN 0721-7595 (Print).

12. Han A., Cao S., Li Y., Wang H., Wei Y., Shao X., Xu F. Sucrose treatment suppresses programmed cell death in broccoli florets by improving mitochondrial physiological properties // Postharvest Biology and Technology. - 2019. - Vol. 156. - doi: 10.1016/j.postharvbio.2019.110932.

13. Hassan F.A.S., Mazrou R., Gaber A., Hassan M.M. Moringa extract preserved the vase life of cut roses through maintaining water relations and enhancing antioxidant machinery // Postharvest Biology and Technology. - 2020. - Vol. 164. - doi: 10.1016/j.postharvbio.2020.111156. 14. He J., Dong Y., Liu X., Wan Y., Gu T., Liu M. Comparison of Chemical Compositions, Antioxidant, and Anti-Photoaging Activities of Paeonia suffruticosa Flowers at Different Flowering Stages // Antioxidants. - 2019. - Vol. 8(9). - P. 345. - doi: 10.3390/antiox8090345.

15. Rogers H., Munne-Bosch S. Production and Scavenging of Reactive Oxygen Species and Redox Signaling during Leaf and Flower Senescence: Similar but Different // Plant Physiol. - 2016. - Vol. 171(3). - P. 1560-1568. - doi: 10.1104/pp.16.00163.

16. Schmitzer V., Veberic R., Osterc G., Stampar F. Changes in the phenolic concentration during flower development of rose 'KORcrisett' // J. Am. Soc. Hortic. Sci. - 2009. - Vol. 134. - P. 491-496. - doi: 10.21273/JASHS.134.5.491.

17. Su J., Nie Y., Zhao G., Cheng D., Wang R., Chen J., Zhang S., Shen W. Endogenous hydrogen gas delays petal senescence and extends the vase life of lisianthus cut flowers // Postharvest Biology and Technology. - 2019. - Vol. 147. - P. 148-155. - doi: 10.1016/j.postharvbio.2018.09.018. 18. Takahama U., Oniki T. A peroxidase/phenolics/ascorbate system can scavenge hydrogen peroxide in plant cells // Physiol. Plant. - 1997. - Vol. 101. - P. 845-852. doi: $10.3390 /$ antiox 2030132 .

\section{ANTIOXIDASE PROPERTIES OF ORNAMENTAL PLANTS}

\section{Panfilova O. F., Pilshchikova N. V.}


The review paper discusses some problems of post-harvest physiology of ornamental plants in connection with the antioxidant systems state during flowers development and aging. Here are presented the achievements of molecular biology in the study of cellular aging regulation mechanisms, and the role of reactive oxygen species and antioxidant systems in this process. Particular attention is paid to changes of polyphenols content in aging petals. It was established that a change in the antioxidant enzyme activity occurs earlier than visible signs of ornamental value loss. During aging, an increased level of ROS is associated not only with increased formation of radicals, but also with the loss of the compensatory function of antioxidant systems. The prospects of using 5 -sulfosalicylic acid to slow the aging of cut flowers are shown.

Key words: antioxidants, autophagy, ornamental plants, vase life, redox signaling, 5-sulfosalicylic acid, petal senescence. 